\title{
The Nexus Between Tourism, Environmental Degradation and Economic Growth
}

\author{
Esra BALLI ${ }^{1}$
}

\begin{abstract}
This study analyzes the impact of tourism on environmental degradation for 32 OECD countries employing panel estimation techniques taking into consideration cross-sectional dependence. The test results demonstrate that tourism and economic growth enhance $\mathrm{CO} 2$ emissions in these countries. The Emirmahmutoglu-Kose panel Granger causality test show that unidirectional association running from tourism to $\mathrm{CO} 2$ emissions exists in OECD countries. For individual countries, bidirectional association between tourism and $\mathrm{CO} 2$ emissions for Canada, a unidirectional association from tourism to $\mathrm{CO} 2$ emissions for Chile, Germany, Ireland, Latvia, and United States exists. Bidirectional relationship is also confirmed between tourist arrivals and GDP for Austria, Germany, and Slovak Republic. Moreover, unidirectional causality is found from tourist arrivals to GDP for Colombia, Latvia, Netherlands, Poland, and Spain.
\end{abstract}

Keywords: Tourism, CO2 emissions, OECD countries, Cross-sectional dependence, Emirmahmutoglu-Kose panel Granger causality test

JEL codes: $\mathrm{C} 23, \mathrm{O} 13, \mathrm{O} 44, \mathrm{Z} 32$

\section{INTRODUCTION}

The nexus between tourism and $\mathrm{CO} 2$ emissions has drawn much research interest recently due to an increasing trend in $\mathrm{CO} 2$ emissions which have been witnessed in the world. Lenzen et al. (2018) estimated the contribution of international tourism account for $8 \%$ of global greenhouse gas emissions. Besides, international tourism may contribute to $\mathrm{CO} 2$ emissions by variety of factors such as tourist activities (Becken and Simmons, 2002; Becken and Patterson, 2006) air travel (Gössling, 2000; Olsthoorn, 2001; Gössling, 2002; Gössling et al. 2002; Gössling et al., 2005; Kuo and Chen, 2009), infrastructure facilities, such as hotels, roads, airports and other tourist establishments (Katircioglu 2014a; Katircioglu et al., 2018). Pang et al. (2013) argue that while tourism may be affected due to the climate changes, at the same time, tourism sector contributes to CO2 emissions. Scott (2011) emphasizes that it is crucial for the sustainability of tourism, the response of tourism to climate change. Besides, Fang et al. (2018) conclude that the examination of the nexus between climate change and tourism has been rapidly increased between 1990 and 2015 analyzing 976 academic papers indicating the importance of tourism on environmental degradation.

International tourism affect economy through different channels, such as creating job opportunities, increasing income levels, and foreign exchange reserves (Balaguer and Cantavella-Jorda, 2002; Dritsakis, 2004; Zhang and Gao, 2016; Alam and Paramati, 2016; Paramati et al., 2017a; Shahzad et al. 2017). According to the report of Travel Tourism Economic Impact (2019) published by World Travel and Tourism Council in 2019, the tourism sector's direct and total contributions to World's GDP in 2018 were $3.2 \%$ and 10\% of total GDP in the world, respectively. The report also indicated that sector generated about 122.8 million jobs (3.8\% of total employment) directly and 318.8 million jobs ( $10 \%$ of total employment) indirectly.

As aforementioned above, it is important to examine the dynamic relationship between tourism, $\mathrm{CO} 2$ emissions, and economic growth in a combined approach to implement policies aiming at higher economic 
growth and number of tourist arrivals without harming environment. The primary purpose of this paper is to examine the relationships among tourism, $\mathrm{CO} 2$ emissions, and economic growth utilizing Common Correlated Effects Mean Group (CCE-MG) developed by Pesaran (2006) and Augmented Mean Group (AMG) estimator proposed by Eberhardt and Teal (2010). This study further employs Emirmahmutoglu-Kose (2011) panel Granger causality test to find the direction of causality between tourism, $\mathrm{CO} 2$ emissions, and economic growth for OECD countries.

\section{LITERATURE REVIEW}

Numerous studies have examined the effect of tourism activities on $\mathrm{CO} 2$ emissions with different contexts. Becken (2013) provides compressive reviews on the relationship between tourism and climate change. The literature review section discusses the nexus between tourism, $\mathrm{CO} 2$ emissions and economic growth.

\section{Tourism and economic growth}

There is mounting mass of literature estimating the nexus between tourism and economic growth in a multivariate framework focusing on a single country or group of countries utilizing various econometric analysis. However, the results of the studies are ambiguous due to the sample of countries, time period, used methodology, selected variables and the data. Besides, comprehensive surveys provide valuable insights on this issue utilizing meta-analysis (Nunkoo et al., 2020; Fonseca and Sánchez Rivero, 2019; Qin et al., 2018; Seetanah et al, 2017; Castro-Nuño et al., 2013). For instance, Fonseca and Sánchez Rivero (2019) employ a meta-analysis on a dataset of 55 studies employing Granger causality test concluding that the tourism-led growth hypothesis is inclined to be confirmed more populated countries and countries which is more specialized in tourism activities. Seetanah et al. (2017) and Nunkoo et al. (2020) emphasize that data, econometric methodology used in the paper affects the results of the studies. Castro-Nuño et al. (2013) conclude that tourism activities contribute to economic growth. Lee and Brahmasrene (2016) conclude that economic growth is positively affected by tourism in Sub-Saharan African countries. For four Pacific Island countries, Narayan et al. (2010) found that a rise in tourism contributes to a rise in economic growth.

The causal relationship between tourism and economic growth has been synthesized into four hypotheses. First hypothesis called tourism-led growth hypothesis asserts that tourism contributes to economic growth positively. A unidirectional causal relationship running from tourism to economic growth was found by many studies of Gunduz and Hatemi-J (2005) for Turkey; Tang et al. (2016) for India; and Tang and Abosedra (2016) for Lebanon; Tang and Tan (2015) for Malaysia; Wu and Wu (2019) for Cambodia, China, and Malaysia. Qureshi et al. (2017) confirm the TLG hypothesis for 37 tourism- induced countries. Isik et al. (2017) confirmed TLG hypothesis for China, and Turkey. Again, similar result obtained for China, Turkey, and for the top seven most visited destinations by Isik et al. (2018). Tang and Abosedra (2014) support the TLG hypothesis in the MENA region. Shahzad et al. (2017) confirm TLG hypothesis for top ten tourism countries. Balli et al. (2019) for Egypt, Italy, and Spain.

Second, economic-driven tourism hypothesis indicates that economic growth leads to an increase in tourism. The second hypothesis confirmed by Isik et al. (2018) for Spain; Oh (2005) for South Korea.

Third hypothesis considers that bidirectional causality exists between tourism and economic growth. Such bidirectional causal relationship confirmed in many countries. For instance, Demiroz and Ongan (2005) and Balli et al. (2019) for Turkey; Cortes-Jimenez and Pulina (2010) and Perles-Ribes et al. (2017) for Spain; Lean and Tang (2010) for Malaysia; Isik et al. (2018) for Germany; Ben Jebli Hadhri (2018) for a sample of top ten tourism countries; Aslan (2014) for Portugal; Dogru and Bulut (2018) for seven Mediterranean countries; Mitra (2019) for 158 countries, dividing into three sub-groups according to the ratio of international tourism receipts to GDP. Akadiri and Akadiri (2019) for 16 selected tourism island countries, Akadiri et al. (2020a) for Germany.

Fourth hypothesis indicates that no causal relationship between tourism and economic growth exists. The fourth hypothesis confirmed by Katircioglu (2009) for Turkey; Isik et al. (2018) for France, Italy, and the US; Aslan (2014) for Malta and Egypt; Wu and Wu (2019) for Japan and Thailand.

\section{Tourism and $\mathrm{CO} 2$ Emissions}

Most studies found a positive impact of tourism on climate change. Dogru et al. (2019) provide evidence of the presence of the vulnerability of tourism sector to climate changes. León et al. (2014) reveal that tourism leads to an increase in $\mathrm{CO} 2$ emissions in the different stage of developed countries. Zaman et al. (2016) point out that tourism expansion contributes the environmental deterioration for 34 countries. Dogan (2017) 
found positive correlation between tourism and $\mathrm{CO} 2$ emissions for top ten most visited destinations.

Paramati et al. (2017a) argue that the tourism affects $\mathrm{CO} 2$ emissions positively, but magnitude differs across developing and developed countries. Paramati et al. (2017b) demonstrated that tourism activities surge $\mathrm{CO}_{2}$ emissions in Eastern EU, while decrease in Western EU. Gulistan et al. (2020) find that tourism negatively affects environment via increasing $\mathrm{CO} 2$ emissions for 112 countries.

In contrast, Lee and Brahmasrene (2013) found that tourism negatively correlated with $\mathrm{CO} 2$ emissions in the EU countries. Brahmasrene and Lee (2017) find that tourism activities reduce $\mathrm{CO} 2$ emissions in the ten Southeast Asian countries. Azam et al. (2018) found that while there is negative association between tourism and environmental pollution for Singapore and Thailand, a positive association found for Malaysia.

Regarding Turkey, Katircioglu (2014a) and Eyuboglu and Uzar (2019) found positive correlation between tourism and $\mathrm{CO} 2$ emissions. Similar finding is obtained for Cyprus by Katircioglu et al. (2014).

Saint Akadiri et al. (2019) point out that tourism gives rise to $\mathrm{CO} 2$ emissions in Turkey. Unidirectional causal association found from tourism to $\mathrm{CO} 2$ emissions by many scholars both for a group of counties or in a country level. Dogan and Aslan, 2017; Dogan et al., 2017 for OECD countries; Sharif et al., 2017 for Pakistan; Solarin, 2014 for Malaysia; Yorucu, 2016 for Turkey; Raza et al., 2017 for the United States. Alola et al. (2019) confirm bidirectional association between tourist arrivals and $\mathrm{CO} 2$ emissions for nine Coastline Mediterranean Countries. Katircioglu et al. (2019) found that tourism growth was positively associated with energy consumption in major tourism countries, suggesting that countries need to invest more renewable energy usage sources for no harm to the environment. Shi et al. (2019) found that net international arrivals positively affect CO2 emissions. Kadir et al. (2019) argued that tourism was positively correlated with $\mathrm{CO} 2$ emissions for 30 selected countries. Akadiri et al. (2020b) found that unidirectional causal association between tourism and $\mathrm{CO} 2$ emissions exists for 16 island developing economies. Eluwole et al. (2020) conclude that tourism contributes to environmental deterioration for 37 developed countries. Katircioglu et al. (2020) pointed out that tourism results in $\mathrm{CO} 2$ emissions in Cyprus.

Apart from that, some other studies also examined whether the tourism-induced EKC hypothesis is valid for countries. Katircioglu (2014b) posits that tourism contributes to environmental degradation in establishing the tourism-induced EKC in Singapore. For Turkey, De Vita et al. (2015) provide evidence for the presence the tourism-induced EKC. For Asia-Pacific countries, Shakouri (2017) provide evidence of the validity of tourism-induced EKC hypothesis. On the other hand, Zhang and Gao (2016) provide no evidence to presence of tourism induced EKC for China.

\section{DATA, METHODOLOGY and MODEL}

The objective of this paper is to examine the relationship between tourism, $\mathrm{CO} 2$ emissions, and economic growth for selected OECD countries, namely Australia, Austria, Belgium, Canada, Chile, Colombia, Czech Republic, Finland, France, Germany, Greece, Iceland, Ireland, Israel, Italy, Japan, Korea, Rep., Latvia, Lithuania, Luxembourg, Mexico, Netherlands, Norway, Poland, Portugal, Slovak Republic, Slovenia, Spain, Sweden, Turkey, United Kingdom, and United States. The dataset for the countries covers the period from 1995 to 2014 and extracted from World Bank. The final period as 2014 was determined by the availability of the data for $\mathrm{CO} 2$ emissions variable. We used $\mathrm{CO} 2$ emissions as the measurement for environmental degradation.

Several study such as Gunduz and Hatemi-J, 2005; Katircioglu et al., 2014; Dogan and Aslan, 2017 used tourist arrivals to measure tourism activities. In the present study, $\mathrm{CO} 2$ emissions is used as an environmental degradation variable. Following Tang et al. (2014), and Lee and Brahmasrene (2013) the model is expressed as follows:

$$
C O_{2 t}=f\left(T O U_{i t}, G D P_{i t}\right)
$$

where $T O U_{i t}$ is number of tourist arrivals, $\mathrm{CO}_{2 i t}$ denotes $\mathrm{CO} 2$ emissions, and $G D P_{i t}$ denotes GDP per capita at 2010 prices.

Cross-sectional dependence and homogeneity tests determine the appropriate econometric methodology in the analysis. Hence, this paper utilized cross-sectional independence test proposed by Pesaran (2004), and homogeneity test developed by Pesaran-Yamagata (2008). After cross-sectional independence and homogeneity test, we investigate the time series properties of the variables utilizing CIPS unit roots developed by Pesaran (2007) that takes into account cross-sectional dependence. Then, according to the data characteristics of the used variables in the study, we employ common correlated effect (CCE) estimator taking into account 
the cross-sectional dependence developed by Pesaran (2006) and Augmented Mean Group (AMG) estimator proposed by Eberhardt and Teal (2010). Finally, in order to determine the direction of causal relationship between tourism, $\mathrm{CO} 2$ emissions and economic growth, we used Emirmahmutoglu-Kose (2011) Granger panel causality test.

\section{EMPIRICAL RESULTS}

Before investigating the linkages among tourism, $\mathrm{CO} 2$ emissions and economic growth, first, we analyze cross-sectional dependence test proposed by Pesaran (2004) between variables and homogeneity test developed by Pesaran-Yamagata (2008) across OECD countries, and the results are illustrated in Table 1 and Table 2.

Table 1: Cross-sectional dependence test results

\begin{tabular}{ll}
\hline InCO2 & $20.86^{*}$ \\
InTOU & $65.32^{*}$ \\
InGDP & $85.74^{*}$ \\
\hline
\end{tabular}

* refers to a significance level of $1 \%$.

According to the results there exists cross-sectional dependence, implying that a shock occurred in one OECD countries may spill over to other countries.

Table 2: Delta Homogeneity Test Results

\begin{tabular}{ll}
\hline$\widetilde{\Delta}$ & $2.729^{*}$ \\
$\widetilde{\Delta} \mathrm{adj}$ & $3.212^{*}$ \\
\hline
\end{tabular}

* refers to a significance level of $1 \%$.

Table 2 reports Delta homogeneity test results. According to the results, we reject the null hypothesis of slope homogeneity, confirming cross-country heterogeneity for OECD countries.

Table 3: The Results of CIPS Unit Root Test

\begin{tabular}{ll}
\hline $\ln C O 2$ & -1.746 \\
$\operatorname{InTOU}$ & -2.196 \\
$\ln G D P$ & -1.296 \\
$\Delta \ln C O 2$ & $-4.142 *$ \\
$\Delta \operatorname{lnTOU}$ & $-3.819^{*}$ \\
$\Delta \operatorname{lnGDP}$ & $-2.802 *$ \\
\hline
\end{tabular}

* refers to a significance level of $1 \%$.

Table 3 presents CIPS unit root test results developed by Pesaran (2007). The results reveal that we fail to reject the null hypothesis of unit root at level, however, we reject the null at first difference.
Table 4: Panel Cointegration Test Results

\begin{tabular}{ll}
\hline Durbin-H Group $18.049 *$ \\
\hline
\end{tabular}

* refers to a significance level of $1 \%$.

According to the Westerlund-Durbin-Hausman (2008) panel cointegration test results tourist arrivals, $\mathrm{CO} 2$ emissions and economic growth are cointegrated.

Table 5: Individual CCE-MG Test Results

\begin{tabular}{|c|c|c|}
\hline \multirow{2}{*}{ Country } & \multicolumn{2}{|c|}{ Dependent variable: $\mathrm{CO} 2$ emissions } \\
\hline & InTOU & InGDP \\
\hline Australia & -0.31 & 0.35 \\
\hline Austria & $0.49 * * *$ & -1.11 \\
\hline Belgium & 0.29 & 1.77 \\
\hline Canada & $0.34^{* *}$ & 0.35 \\
\hline Chile & 0.21 & 0.56 \\
\hline Colombia & -0.04 & $1.40^{*}$ \\
\hline Czech Republic & $0.18^{* *}$ & -0.22 \\
\hline Finland & 0.20 & $-2.69 * *$ \\
\hline France & -0.01 & 0.98 \\
\hline Germany & -0.12 & $0.77^{*}$ \\
\hline Greece & 0.08 & $0.41^{* *}$ \\
\hline Iceland & $0.42^{* *}$ & 0.75 \\
\hline Ireland & 0.32 & $0.65^{*}$ \\
\hline Israel & -0.04 & $2.28^{*}$ \\
\hline Italy & $-0.27^{*}$ & $1.54^{*}$ \\
\hline Japan & -0.05 & $2.49 *$ \\
\hline Korea, Rep. & 0.23 & $1.13^{*}$ \\
\hline Latvia & $0.52^{*}$ & -0.51 \\
\hline Lithuania & -0.10 & $1.06^{*}$ \\
\hline Luxembourg & -0.01 & -0.64 \\
\hline Mexico & $-0.20^{* *}$ & 0.22 \\
\hline Netherlands & -0.02 & $-0.58^{* * *}$ \\
\hline Norway & 0.31 & 1.51 \\
\hline Poland & -0.18 & $0.85^{*}$ \\
\hline Portugal & 0.24 & $2.12^{* * *}$ \\
\hline Slovak Republic & $0.14^{* *}$ & $0.25^{* *}$ \\
\hline Slovenia & 0.12 & $1.36^{*}$ \\
\hline Spain & 0.33 & $2.37^{*}$ \\
\hline Sweden & 0.04 & $2.22^{* *}$ \\
\hline Turkey & -0.01 & $1.18^{*}$ \\
\hline United Kingdom & -0.13 & $0.72^{* *}$ \\
\hline United States & 0.05 & $1.38^{*}$ \\
\hline Panel & $0.08^{* *}$ & $0.78^{*}$ \\
\hline
\end{tabular}


The results of CCE-MG estimation are presented in Table 5. CCE-MG test results show that an increase in tourist arrivals lead to an increase in $\mathrm{CO} 2$ emissions in Austria, Canada, Czech Republic, Iceland, Latvia, Mexico, and Slovak Republic. Besides, an increase in GDP results in an increase in $\mathrm{CO} 2$ emissions most OECD countries.

Table 6: Individual AMG Test Results

\begin{tabular}{|c|c|c|}
\hline \multirow{2}{*}{ Country } & \multicolumn{2}{|c|}{ Dependent variable: $\mathrm{CO} 2$ emissions } \\
\hline & InTOU & InGDP \\
\hline Australia & $-0.33^{* *}$ & $1.26^{*}$ \\
\hline Austria & 0.48 & $1.43^{*}$ \\
\hline Belgium & 0.30 & 0.11 \\
\hline Canada & $0.37^{*}$ & $0.65^{*}$ \\
\hline Chile & 0.21 & 0.56 \\
\hline Colombia & $-0.10^{* *}$ & $1.99 *$ \\
\hline Czech Republic & -0.13 & $0.46^{*}$ \\
\hline Finland & 0.07 & $0.86^{*}$ \\
\hline France & -0.01 & $1.02 *$ \\
\hline Germany & -0.01 & 0.38 \\
\hline Greece & 0.11 & $0.67^{*}$ \\
\hline Iceland & $0.39^{* *}$ & $0.27^{* *}$ \\
\hline Ireland & -0.13 & $0.77^{*}$ \\
\hline Israel & $-0.07^{* * *}$ & $2.02 *$ \\
\hline Italy & $-0.28^{*}$ & $1.75^{*}$ \\
\hline Japan & -0.05 & $1.27^{*}$ \\
\hline Korea, Rep. & $0.49 *$ & 0.54 \\
\hline Latvia & $0.62^{*}$ & $-0.70^{*}$ \\
\hline Lithuania & -0.15 & $0.36^{* * *}$ \\
\hline Luxembourg & -0.39 & $1.16^{*}$ \\
\hline Mexico & -0.26 & $0.82^{*}$ \\
\hline Netherlands & $-0.09 * * *$ & 0.13 \\
\hline Norway & 0.10 & 1.23 \\
\hline Poland & $0.26^{* *}$ & $0.53^{* *}$ \\
\hline Portugal & 0.20 & $1.68^{*}$ \\
\hline Slovak Republic & $0.09^{* *}$ & $0.17^{* *}$ \\
\hline Slovenia & 0.04 & $0.66^{*}$ \\
\hline Spain & $0.49 * *$ & $1.12^{*}$ \\
\hline Sweden & 0.11 & 0.10 \\
\hline Turkey & 0.04 & $0.64^{*}$ \\
\hline United Kingdom & -0.01 & $0.67^{*}$ \\
\hline United States & 0.01 & $0.74^{*}$ \\
\hline Panel & $0.07^{* * *}$ & $0.79 *$ \\
\hline
\end{tabular}

AMG test results are illustrated in Table 6. The results reveal that a rise in tourism increases environmental deterioration in Australia, Canada, Colombia, Iceland, Israel, Italy, Latvia, Netherlands, Poland, Slovakia, and Spain. Similar to the panel CCE-MG test results, panel AMG results show that GDP was positively correlated with $\mathrm{CO} 2$ emissions in most OECD countries. The surge in GDP results in increase in $\mathrm{CO} 2$ emissions in most OECD countries.

In addition, panel CCE-MG and panel AMG estimators reveal that the $\mathrm{CO} 2$ are positively affected by tourism and economic growth. The panel CCE-MG estimation results exhibit that an $1 \%$ increase in tourism contributes to $\mathrm{CO}$ emissions by $0.08 \%$. Moreover, a $1 \%$ increase in GDP leads to a rise in $\mathrm{CO} 2$ emissions by $0.78 \%$ in a panel of OECD countries.

Finally, causality between TOU and $\mathrm{CO} 2 ; \mathrm{TOU}$ and GDP, GDP and $\mathrm{CO} 2$ was tested by Emirmahmutoglu-Kose (2011) panel Granger causality test.

Table 7 shows Emirmahmutoglu-Kose panel Granger causality test results between $\mathrm{TOU}$ and $\mathrm{CO} 2$ emissions for 32 OECD countries. The results show that unidirectional association from TOU to $\mathrm{CO} 2$ emissions in OECD countries exists. For individual countries, bidirectional association between TOU and $\mathrm{CO} 2$ emissions for Canada is found. The results also show that a unidirectional association from TOU to CO2 emissions for Chile, Germany, Ireland, Latvia, and United States exists. 
Table 7: Emirmahmutoglu-Kose Granger panel causality test results

\begin{tabular}{|c|c|c|c|c|c|c|}
\hline \multirow{2}{*}{ Country } & \multirow[b]{2}{*}{ Lag } & \multicolumn{2}{|l|}{$\mathrm{TOU}=>\mathrm{CO} 2$} & \multirow[b]{2}{*}{ Lag } & \multicolumn{2}{|l|}{$\mathrm{CO} 2=>\mathrm{TOU}$} \\
\hline & & Wald Statistic & p-value & & Wald Statistic & $p$-value \\
\hline Australia & 1 & 1.255 & 0.263 & 1 & 1.875 & 0.171 \\
\hline Austria & 1 & 0.129 & 0.719 & 1 & 3.033 & $0.082^{* * *}$ \\
\hline Belgium & 2 & 0.952 & 0.621 & 2 & 17.479 & $0.000^{*}$ \\
\hline Canada & 1 & 5.711 & $0.017^{* *}$ & 1 & 6.054 & $0.014^{* *}$ \\
\hline Chile & 2 & 10.945 & $0.004^{*}$ & 2 & 10.676 & $0.005^{*}$ \\
\hline Colombia & 2 & 2.215 & 0.330 & 2 & 3.155 & 0.207 \\
\hline Czech Republic & 1 & 0.744 & 0.388 & 1 & 2.380 & 0.123 \\
\hline Finland & 1 & 0.125 & 0.724 & 1 & 3.389 & $0.066^{* * * *}$ \\
\hline France & 4 & 0.967 & 0.617 & 2 & 0.594 & 0.743 \\
\hline Germany & 1 & 3.876 & $0.049^{* *}$ & 1 & 0.390 & 0.532 \\
\hline Greece & 2 & 0.568 & 0.753 & 3 & 6.589 & $0.086^{* * *}$ \\
\hline Iceland & 3 & 1.274 & 0.735 & 1 & 0.035 & 0.851 \\
\hline Ireland & 3 & 8.088 & $0.044^{* *}$ & 1 & 0.024 & 0.876 \\
\hline Israel & 1 & 1.604 & 0.205 & 1 & 1.766 & 0.184 \\
\hline Italy & 1 & 0.768 & 0.381 & 2 & 12.373 & $0.002^{*}$ \\
\hline Japan & 3 & 1.561 & 0.668 & 1 & 0.000 & 0.998 \\
\hline Korea, Rep. & 1 & 0.214 & 0.644 & 1 & 0.266 & 0.606 \\
\hline Latvia & 2 & 6.654 & $0.036^{* *}$ & 1 & 0.082 & 0.775 \\
\hline Lithuania & 1 & 0.633 & 0.426 & 1 & 0.723 & 0.395 \\
\hline Luxembourg & 2 & 0.135 & 0.935 & 2 & 2.080 & 0.353 \\
\hline Mexico & 1 & 0.470 & 0.493 & 1 & 0.191 & 0.662 \\
\hline Netherlands & 3 & 4.075 & 0.253 & 2 & 9.843 & $0.007^{*}$ \\
\hline Norway & 1 & 1.467 & 0.226 & 1 & 0.164 & 0.685 \\
\hline Poland & 3 & 2.087 & 0.554 & 1 & 0.012 & 0.912 \\
\hline Portugal & 2 & 1.014 & 0.602 & 1 & 0.188 & 0.664 \\
\hline Slovak Republic & 1 & 0.343 & 0.558 & 1 & 0.733 & 0.392 \\
\hline Slovenia & 1 & 1.007 & 0.316 & 2 & 0.886 & 0.347 \\
\hline Spain & 1 & 0.000 & 0.993 & 1 & 0.868 & 0.648 \\
\hline Sweden & 1 & 0.754 & 0.385 & 1 & 2.206 & 0.137 \\
\hline Turkey & 2 & 1.351 & 0.509 & 1 & 0.470 & 0.493 \\
\hline United Kingdom & 3 & 0.179 & 0.981 & 2 & 0.152 & 0.927 \\
\hline United States & 1 & 8.192 & $0.004^{*}$ & 1 & 0.139 & 0.709 \\
\hline Panel Fisher & & 84.897 & & & $110.119 * *$ & \\
\hline
\end{tabular}

Table 8 exhibits Emirmahmutoglu-Kose panel Granger causality test results between TOU and GDP for 32 OECD countries. The results show that bidirectional relationship between tourist arrivals and GDP for Aust- ria, Germany, and Slovak Republic exists, confirming the feedback hypothesis. Unidirectional causality is confirmed from tourist arrivals to GDP for Colombia, Latvia, Netherlands, Poland, and Spain. 
Table 8: Emirmahmutoglu-Kose panel Granger causality test results

\begin{tabular}{|c|c|c|c|c|c|c|}
\hline \multirow[b]{2}{*}{ Country } & \multirow[b]{2}{*}{ Lag } & \multicolumn{2}{|c|}{$\mathrm{TOU}=>\mathrm{GDP}$} & \multirow[b]{2}{*}{ Lag } & \multicolumn{2}{|c|}{$\mathrm{GDP}=>\mathrm{TOU}$} \\
\hline & & $\begin{array}{l}\text { Wald } \\
\text { Statistic }\end{array}$ & p-value & & $\begin{array}{l}\text { Wald } \\
\text { Statistic }\end{array}$ & p-value \\
\hline Australia & 2 & 1.792 & 0.408 & 2 & 1.759 & 0.415 \\
\hline Austria & 1 & 5.426 & $0.020^{* *}$ & 1 & 4.139 & $0.042^{* *}$ \\
\hline Belgium & 1 & 0.325 & 0.569 & 1 & 0.421 & 0.516 \\
\hline Canada & 1 & 0.213 & 0.644 & 1 & 0.103 & 0.748 \\
\hline Chile & 1 & 3.457 & $0.063^{* * *}$ & 1 & 0.437 & 0.509 \\
\hline Colombia & 1 & 6.869 & $0.009^{*}$ & 1 & 0.023 & 0.879 \\
\hline Czech Republic & 1 & 0.052 & 0.820 & 1 & 0.004 & 0.951 \\
\hline Finland & 1 & 0.378 & 0.539 & 1 & 0.002 & 0.962 \\
\hline France & 1 & 0.055 & 0.814 & 1 & 0.700 & 0.403 \\
\hline Germany & 1 & 3.240 & $0.072^{* * *}$ & 1 & 5.837 & $0.016^{* *}$ \\
\hline Greece & 2 & 3.810 & 0.149 & 1 & 3.428 & 0.180 \\
\hline Iceland & 1 & 0.063 & 0.802 & 2 & 1.072 & 0.300 \\
\hline Ireland & 1 & 0.302 & 0.582 & 1 & 0.373 & 0.541 \\
\hline Israel & 1 & 0.923 & 0.337 & 1 & 4.241 & $0.039 * *$ \\
\hline Italy & 1 & 0.173 & 0.678 & 1 & 0.046 & 0.830 \\
\hline Japan & 1 & 0.419 & 0.517 & 1 & 0.235 & 0.628 \\
\hline Korea, Rep. & 1 & 1.266 & 0.261 & 1 & 0.000 & 0.992 \\
\hline Latvia & 3 & 7.838 & $0.049^{* *}$ & 3 & 0.365 & 0.947 \\
\hline Lithuania & 1 & 1.819 & 0.177 & 1 & 0.131 & 0.718 \\
\hline Luxembourg & 1 & 0.053 & 0.818 & 1 & 1.148 & 0.284 \\
\hline Mexico & 1 & 0.309 & 0.578 & 1 & 0.075 & 0.785 \\
\hline Netherlands & 2 & 5.022 & $0.081^{* * *}$ & 2 & 2.121 & 0.346 \\
\hline Norway & 1 & 0.216 & 0.642 & 1 & 0.307 & 0.579 \\
\hline Poland & 2 & 4.883 & $0.087^{* * *}$ & 2 & 0.056 & 0.972 \\
\hline Portugal & 1 & 2.522 & 0.112 & 1 & 0.104 & 0.748 \\
\hline Slovak Republic & 3 & 8.535 & $0.036^{* *}$ & 3 & 6.254 & $0.100^{* * *}$ \\
\hline Slovenia & 1 & 0.195 & 0.658 & 1 & 1.197 & 0.274 \\
\hline Spain & 3 & 8.891 & $0.031^{* *}$ & 3 & 0.694 & 0.874 \\
\hline Sweden & 1 & 0.432 & 0.511 & 1 & 0.706 & 0.401 \\
\hline Turkey & 1 & 0.010 & 0.922 & 1 & 1.476 & 0.224 \\
\hline United Kingdom & 1 & 0.084 & 0.772 & 1 & 1.205 & 0.272 \\
\hline United States & 2 & 0.747 & 0.688 & 2 & 1.109 & 0.574 \\
\hline Panel Fisher & & 89.587 & & & 60.387 & \\
\hline
\end{tabular}

Table 9 reports Emirmahmutoglu-Kose panel Granger causality test results between GDP and $\mathrm{CO} 2$ for OECD countries. The test results provide evidence of bidirectional causal association between GDP and $\mathrm{CO} 2$ emissions Slovenia, and unidirectional causal associati- on from GDP to CO2 emissions for Israel, South Korea, Netherlands, Poland and United States. Moreover, unidirectional causal association is confirmed running from $\mathrm{CO} 2$ emission to GDP for Austria, Belgium, Canada, Finland, and Luxembourg. 
Table 9: Emirmahmutoglu-Kose panel Granger causality test results

\begin{tabular}{|c|c|c|c|c|c|c|}
\hline \multirow[b]{2}{*}{ Country } & \multirow[b]{2}{*}{ Lag } & \multicolumn{2}{|c|}{$\mathrm{GDP}=>\mathrm{CO} 2$} & \multirow[b]{2}{*}{ Lag } & \multicolumn{2}{|c|}{$\mathrm{CO} 2=>\mathrm{GDP}$} \\
\hline & & $\begin{array}{l}\text { Wald } \\
\text { Statistic }\end{array}$ & $p$-value & & $\begin{array}{l}\text { Wald } \\
\text { Statistic }\end{array}$ & $p$-value \\
\hline Australia & 1 & 0.331 & 0.565 & 1 & 1.875 & 0.171 \\
\hline Austria & 1 & 0.013 & 0.911 & 1 & 3.033 & $0.082^{* * *}$ \\
\hline Belgium & 2 & 0.104 & 0.747 & 2 & 17.479 & $0.000^{*}$ \\
\hline Canada & 1 & 0.025 & 0.873 & 1 & 6.054 & $0.014^{* *}$ \\
\hline Chile & 1 & 0.065 & 0.798 & 2 & 10.676 & $0.005^{*}$ \\
\hline Colombia & 1 & 1.386 & 0.798 & 2 & 3.155 & 0.207 \\
\hline Czech Republic & 1 & 0.351 & 0.553 & 1 & 2.380 & 0.123 \\
\hline Finland & 1 & 2.258 & 0.133 & 1 & 3.389 & $0.066^{* * *}$ \\
\hline France & 3 & 1.141 & 0.767 & 2 & 0.594 & 0.743 \\
\hline Germany & 3 & 6.156 & 0.104 & 1 & 0.056 & 0.812 \\
\hline Greece & 3 & 2.982 & 0.394 & 2 & 1.888 & 0.389 \\
\hline Iceland & 3 & 5.076 & 0.166 & 3 & 4.951 & 0.175 \\
\hline Ireland & 1 & 0.039 & 0.844 & 1 & 0.011 & 0.917 \\
\hline Israel & 1 & 7.481 & $0.006^{*}$ & 1 & 1.557 & 0.212 \\
\hline Italy & 1 & 0.119 & 0.731 & 1 & 0.350 & 0.554 \\
\hline Japan & 1 & 0.317 & 0.573 & 1 & 0.102 & 0.750 \\
\hline Korea, Rep. & 1 & 3.492 & $0.062^{* * *}$ & 1 & 2.563 & 0.109 \\
\hline Latvia & 2 & 1.520 & 0.468 & 2 & 1.415 & 0.493 \\
\hline Lithuania & 1 & 0.315 & 0.575 & 1 & 0.014 & 0.905 \\
\hline Luxembourg & 2 & 0.301 & 0.860 & 2 & 11.059 & $0.004^{*}$ \\
\hline Mexico & 1 & 0.366 & 0.545 & 1 & 0.965 & 0.326 \\
\hline Netherlands & 3 & 10.291 & $0.016^{* *}$ & 1 & 0.178 & 0.674 \\
\hline Norway & 1 & 0.955 & 0.328 & 1 & 0.474 & 0.491 \\
\hline Poland & 1 & 3.044 & $0.081^{* * *}$ & 3 & 4.620 & 0.202 \\
\hline Portugal & 1 & 0.148 & 0.700 & 1 & 0.046 & 0.831 \\
\hline Slovak Republic & 1 & 0.084 & 0.773 & 1 & 0.000 & 0.984 \\
\hline Slovenia & 1 & 3.881 & $0.049 * *$ & 3 & 8.834 & $0.032^{* *}$ \\
\hline Spain & 1 & 0.311 & 0.577 & 2 & 2.329 & 0.312 \\
\hline Sweden & 1 & 1.006 & 0.316 & 1 & 0.028 & 0.866 \\
\hline Turkey & 1 & 1.049 & 0.306 & 1 & 0.517 & 0.472 \\
\hline United Kingdom & 3 & 2.470 & 0.481 & 1 & 0.762 & 0.383 \\
\hline United States & 3 & 12.027 & $0.007^{*}$ & 3 & 0.674 & 0.879 \\
\hline Panel Fisher & & 83.005 & & & $107.827 *$ & \\
\hline
\end{tabular}

\section{CONCLUSION}

This paper investigates the link between tourism, CO2 emissions, and economic growth utilizing CCE approach developed by Pesaran (2006) and AMG approach proposed by Eberhardt and Teal (2010) for selected OECD countries for the period of 1995-2014. This study lastly utilizes the Emirmahmutoglu-Kose panel Granger causality test so as to demonstrate the direction of causality among tourism, $\mathrm{CO} 2$ emissions, and economic growth for the countries under investigation.

Given the span of data set and the CCE and AMG results, the results show that tourism enhances $\mathrm{CO} 2$ emissions in OECD countries, suggesting that an 
increase in tourist arrivals leads to an increase in $\mathrm{CO} 2$ emissions. Also, our results reveal that economic growth contributes to environmental degradation in these countries. Moreover, Emirmahmutoglu-Kose panel Granger causality test provide evidence of unidirectional association running from tourism to $\mathrm{CO} 2$ emissions in OECD countries.

Given these results, we strongly suggest more attention on implementation of policies for the sustainability of tourism. The findings show that while tourism contributes to economic growth in OECD countries, it also increases $\mathrm{CO} 2$ emissions. This imply that policy makers should follow the policies, aiming at not only to expand the tourism but also reduce $\mathrm{CO} 2$ emissions. Therefore, stakeholders should take into account investing in more clean energy sources and especially clean transportation applications and decreasing the share of fossil fuel energy in tourism activities to lower the harm to the environment while promoting economic growth at the same time. 


\section{References}

Akadiri, S. S., \& Akadiri, A. C. (2019). Examining the causal relationship between tourism, exchange rate, and economic growth in tourism island states: evidence from second-generation panel. International Journal of Hospitality \& Tourism Administration, 1-16.

Akadiri, S. S., Alola, A. A., \& Uzuner, G. (2020a). Economic policy uncertainty and tourism: evidence from the heterogeneous panel. Current Issues in Tourism, 23(20), 2507-2514.

Akadiri, S. S., Lasisi, T. T., Uzuner, G., \& Akadiri, A. C. (2020b). Examining the causal impacts of tourism, globalization, economic growth and carbon emissions in tourism island territories: bootstrap panel Granger causality analysis. Current Issues in Tourism, 23(4), 470-484.

Alam, M. S., \& Paramati, S. R. (2016). The impact of tourism on income inequality in developing economies: Does Kuznets curve hypothesis exist?. Annals of Tourism Research, 61, 111-126.

Alola, A. A., Eluwole, K. K., Alola, U. V., Lasisi, T. T., \& Avci, T. (2019). Environmental quality and energy import dynamics. Management of Environmental Quality: An International Journal, 31, 665-682.

Aslan, A. (2014). Tourism development and economic growth in the Mediterranean countries: Evidence from panel Granger causality tests. Current issues in Tourism, 17(4), 363-372.

Azam, M., Alam, M. M., \& Hafeez, M. H. (2018). Effect of tourism on environmental pollution: Further evidence from Malaysia, Singapore and Thailand. Journal of cleaner production, 190, 330-338.

Balaguer, J., \& Cantavella-Jorda, M. (2002). Tourism as a longrun economic growth factor: the Spanish case. Applied economics, 34(7), 877-884.

Balli, E., Sigeze, C., Manga, M., Birdir, S., \& Birdir, K. (2019). The relationship between tourism, $\mathrm{CO} 2$ emissions and economic growth: a case of Mediterranean countries. Asia Pacific Journal of Tourism Research, 24(3), 219-232.

Becken, S. (2013). A review of tourism and climate change as an evolving knowledge domain. Tourism Management Perspectives, 6, 53-62.

Becken, S., \& Patterson, M. (2006). Measuring national carbon dioxide emissions from tourism as a key step towards achieving sustainable tourism. Journal of Sustainable Tourism, 14(4), 323-338.

Becken, S., \& Simmons, D. G. (2002). Understanding energy consumption patterns of tourist attractions and activities in New Zealand. Tourism Management, 23(4), 343-354.

Ben Jebli, M., \& Hadhri, W. (2018). The dynamic causal links between $\mathrm{CO} 2$ emissions from transport, real GDP, energy use and international tourism. International Journal of Sustainable Development \&World Ecology, 25(6), 568-577.
Brahmasrene, T., \& Lee, J. W. (2017). Assessing the dynamic impact of tourism, industrialization, urbanization, and globalization on growth and environment in Southeast Asia. International Journal of Sustainable Development \& World Ecology, 24(4), 362-371.

Castro-Nuño, M., Molina-Toucedo, J. A., \& Pablo-Romero, M. P. (2013). Tourism and GDP: A meta-analysis of panel data studies. Journal of Travel research, 52(6), 745-758.

Cortes-Jimenez, I., \& Pulina, M. (2010). Inbound tourism and long-run economic growth. Current Issues in Tourism, 13(1), 61-74.

De Vita, G., Katircioglu, S., Altinay, L., Fethi, S., \& Mercan, M. (2015). Revisiting the environmental Kuznets curve hypothesis in a tourism development context. Environmental Science and Pollution Research, 22(21), 16652-16663.

Demiroz, D. M., \& Ongan, S. (2005). The contribution of tourism to the long-run Turkish economic growth. Ekonomický časopis, 9, 880-894.

Dogan, E. (2017). CO2 Emissions, Real GDP, Renewable Energy and Tourism: Evidence from Panel of the Most-Visited Countries, Statistika, 97 (3): 63-76.

Dogan, E., \& Aslan, A. (2017). Exploring the relationship among CO2 emissions, real GDP, energy consumption and tourism in the EU and candidate countries: Evidence from panel models robust to heterogeneity and cross-sectional dependence. Renewable and Sustainable Energy Reviews, 77, 239-245.

Dogan, E., Seker, F., \& Bulbul, S. (2017). Investigating the impacts of energy consumption, real GDP, tourism and trade on $\mathrm{CO} 2$ emissions by accounting for cross-sectional dependence: A panel study of OECD countries. Current Issues in Tourism, 20(16), 1701-1719.

Dogru, T., \& Bulut, U. (2018). Is tourism an engine for economic recovery? Theory and empirical evidence. Tourism Management, 67, 425-434.

Dogru, T., Marchio, E. A., Bulut, U., \& Suess, C. (2019). Climate change: Vulnerability and resilience of tourism and the entire economy. Tourism Management, 72, 292-305.

Dritsakis, N. (2004). Tourism as a long-run economic growth factor: an empirical investigation for Greece using causality analysis. Tourism economics, 10(3), 305-316.

Eberhardt, M., \& Teal, F. (2010). Productivity Analysis in Global Manufacturing Production. Economics Series Working Papers, 515, University of Oxford, Department of Economics.

Eluwole, K. K., Saint Akadiri, S., Alola, A. A., \& Etokakpan, M. U. (2020). Does the interaction between growth determinants a drive for global environmental sustainability? Evidence from world top 10 pollutant emissions countries. Science of The Total Environment, 705, 135972. 
Emirmahmutoglu, F., \& Kose, N. (2011). Testing for Granger causality in heterogeneous mixed panels. Economic Modelling, 28(3), 870-876.

Eyuboglu, K., \& Uzar, U. (2019). The impact of tourism on CO2 emission in Turkey. Current Issues in Tourism, 1-15.

Fang, Y., Yin, J., \& Wu, B. (2018). Climate change and tourism: A scientometric analysis using CiteSpace. Journal of Sustainable Tourism, 26(1), 108-126.

Fonseca, N., \& Sánchez Rivero, M. (2020). Granger Causality between Tourism and Income: A Meta-regression Analysis. Journal of Travel Research, 59(4), 642-660.

Gössling, S. (2000). Sustainable tourism development in developing countries: Some aspects of energy use. Journal of sustainable tourism, 8(5), 410-425.

Gössling, S. (2002). Global environmental consequences of tourism. Global environmental change, 12(4), 283-302.

Gössling, S., Hansson, C. B., Hörstmeier, O., \& Saggel, S. (2002). Ecological footprint analysis as a tool to assess tourism sustainability. Ecological Economics, 43(2), 199-211.

Gössling, S., Peeters, P., Ceron, J. P., Dubois, G., Patterson, T., $\&$ Richardson, R. B. (2005). The eco-efficiency of tourism. Ecological economics, 54(4), 417-434.

Gulistan, A., Tariq, Y. B., \& Bashir, M. F. (2020). Dynamic relationship among economic growth, energy, trade openness, tourism, and environmental degradation: fresh global evidence. Environmental Science and Pollution Research, $1-11$.

Gunduz, L., \& Hatemi-J, A. (2005). Is the tourism-led growth hypothesis valid for Turkey?. Applied Economics Letters, 12(8), 499-504.

Işik, C., Doğan, E., \& Ongan, S. (2017). Analyzing the tourism-energy-growth nexus for the top 10 most-visited countries. Economies, 5(4), 40.

Isik, C., Dogru, T., \& Turk, E. S. (2018). A nexus of linear and nonlinear relationships between tourism demand, renewable energy consumption, and economic growth: Theory and evidence. International Journal of Tourism Research, 20(1), 38-49.

Kadir, N., Nayan, S., Noor, A. N. M., \& Zakaria, D. A. (2019). Tourism, Carbon Dioxide Emissions and Economic Growth: Evidence from Panel Data. In Proceedings of the Second International Conference on the Future of ASEAN (ICoFA) 2017-Volume 1 (pp. 391-398). Springer, Singapore.

Katircioglu, S. T. (2009). Revisiting the tourism-led-growth hypothesis for Turkey using the bounds test and Johansen approach for cointegration. Tourism Management, 30(1), 17-20.

Katircioglu, S. T. (2014a). International tourism, energy consumption, and environmental pollution: The case of Turkey. Renewable and Sustainable Energy Reviews, 36, 180-187.
Katircioglu, S. T. (2014b). Testing the tourism-induced EKC hypothesis: The case of Singapore. Economic Modelling, 41, 383-391.

Katircioglu, S. T., Feridun, M., \& Kilinc, C. (2014). Estimating tourism-induced energy consumption and $\mathrm{CO} 2$ emissions: The case of Cyprus. Renewable and Sustainable Energy Reviews, 29, 634-640.

Katircioglu, S., Gokmenoglu, K. K., \& Eren, B. M. (2018). Testing the role of tourism development in ecological footprint quality: evidence from top 10 tourist destinations. Environmental Science and Pollution Research, 25(33), 33611-33619.

Katircioglu, S., Gokmenoglu, K. K., \& Eren, B. M. (2019). The role of tourism growth in generating additional energy consumption: empirical evidence from major tourist destinations. Environmental and Ecological Statistics, 26(4), 303-323.

Katircioglu, S., Saqib, N., Katircioglu, S., Kilinc, C. C., \& Gul, H. (2020). Estimating the effects of tourism growth on emission pollutants: empirical evidence from a small island, Cyprus. Air Quality, Atmosphere \& Health, 1-7.

Kuo, N. W., \& Chen, P. H. (2009). Quantifying energy use, carbon dioxide emission, and other environmental loads from island tourism based on a life cycle assessment approach. Journal of Cleaner Production, 17(15), 1324-1330.

Lean, H. H., \& Tang, C. F. (2010). Is the tourism-led growth hypothesis stable for Malaysia? A note. International Journal of Tourism Research, 12(4), 375-378.

Lee, J. W., \& Brahmasrene, T. (2013). Investigating the influence of tourism on economic growth and carbon emissions: Evidence from panel analysis of the European Union. Tourism management, 38, 69-76.

Lee, J. W., \& Brahmasrene, T. (2016). Tourism effects on the environment and economic sustainability of sub-Saharan Africa. International Journal of Sustainable Development \&World Ecology, 23(3), 221-232.

Lenzen, M., Sun, Y. Y., Faturay, F., Ting, Y. P., Geschke, A., \& Malik, A. (2018). The carbon footprint of global tourism. Nature Climate Change, 8(6), 522-528.

León, C. J., Arana, J. E., \& Hernández Alemán, A. (2014). CO2 Emissions and tourism in developed and less developed countries. Applied Economics Letters, 21(16), 1169-1173.

Mitra, S. K. (2019). Is tourism-led growth hypothesis still valid?. International Journal of Tourism Research, 21(5), 615-624.

Narayan, P. K., Narayan, S., Prasad, A., \& Prasad, B. C. (2010). Tourism and economic growth: a panel data analysis for Pacific Island countries. Tourism economics, 16(1), 169183.

Nunkoo, R., Seetanah, B., Jaffur, Z. R. K., Moraghen, P. G. W., \& Sannassee, R. V. (2020). Tourism and economic growth: A meta-regression analysis. Journal of Travel Research, 59(3), 404-423. 
Oh, C. O. (2005). The contribution of tourism development to economic growth in the Korean economy. Tourism management, 26(1), 39-44.

Olsthoorn, X. (2001). Carbon dioxide emissions from international aviation: 1950-2050. Journal of Air Transport Management, 7(2), 87-93.

Pang, S. F., McKercher, B., \& Prideaux, B. (2013). Climate change and tourism: An overview. Asia Pacific Journal of Tourism Research, 18(1-2), 4-20.

Paramati, S. R., Alam, M. S., \& Chen, C. F. (2017a). The effects of tourism on economic growth and $\mathrm{CO} 2$ emissions: a comparison between developed and developing economies. Journal of Travel Research, 56(6), 712-724.

Paramati, S. R., Shahbaz, M., \& Alam, M. S. (2017b). Does tourism degrade environmental quality? A comparative study of Eastern and Western European Union. Transportation Research Part D: Transport and Environment, 50, 1-13.

Perles-Ribes, J. F., Ramón-Rodríguez, A. B., Rubia, A., \& Moreno-Izquierdo, L. (2017). Is the tourism-led growth hypothesis valid after the global economic and financial crisis? The case of Spain 1957-2014. Tourism Management, 61, 96-109.

Pesaran, H. M. (2004). General diagnostic tests for cross-sectional dependence in panels. University of Cambridge, Cambridge Working Papers in Economics, 435.

Pesaran, M. H. (2006). Estimation and inference in large heterogeneous panels with a multifactor error structure. Econometrica, 74(4), 967-1012.

Pesaran, M. H. (2007). A simple panel unit root test in the presence of cross-section dependence. Journal of applied econometrics, 22(2), 265-312.

Pesaran, M. H., \&Yamagata, T. (2008). Testing slope homogeneity in large panels. Journal of econometrics, 142(1), 50-93.

Qin, Y., Luo, Y., Zhao, Y., \& Zhang, J. (2018). Research on relationship between tourism income and economic growth based on meta-analysis. Applied Mathematics and Nonlinear Sciences, 3(1), 105-114.

Qureshi, M. I., Hassan, M. A., Hishan, S. S., Rasli, A. M., \& Zaman, K. (2017). Dynamic linkages between sustainable tourism, energy, health and wealth: Evidence from top 80 international tourist destination cities in 37 countries. Journal of cleaner production, 158, 143-155.

Raza, S. A., Sharif, A., Wong, W. K., \& Karim, M. Z. A. (2017). Tourism development and environmental degradation in the United States: Evidence from wavelet-based analysis. Current Issues in Tourism, 20(16), 1768-1790.

Saint Akadiri, S., Alola, A. A., \& Akadiri, A. C. (2019). The role of globalization, real income, tourism in environmental sustainability target. Evidence from Turkey. Science of the total environment, 687, 423-432.

Scott, D. (2011). Why sustainable tourism must address climate change. Journal of Sustainable Tourism, 19(1), 17-34.
Seetanah, B., Nunkoo, R., Sannassee, R. V., Georges, P., \& Jaffur, W. M. Z. R. K. (2017). A meta-analysis of the tourism and economic growth nexus. BESTEN Think Tank XVII: Innovation and Progress in Sustainable Tourism, 180.

Shahzad, S. J. H., Shahbaz, M., Ferrer, R., \& Kumar, R. R. (2017). Tourism-led growth hypothesis in the top ten tourist destinations: New evidence using the quantile-on-quantile approach. Tourism Management, 60, 223-232.

Shakouri, B., Khoshnevis Yazdi, S., \& Ghorchebigi, E. (2017). Does tourism development promote $\mathrm{CO} 2$ emissions? Anatolia, 28(3), 444-452.

Sharif, A., Afshan, S., \& Nisha, N. (2017). Impact of tourism on $\mathrm{CO} 2$ emission: evidence from Pakistan. Asia Pacific Journal of Tourism Research, 22(4), 408-421.

Shi, H., Li, X., Zhang, H., Liu, X., Li, T., \& Zhong, Z. (2019). Global difference in the relationships between tourism, economic growth, $\mathrm{CO} 2$ emissions, and primary energy consumption. Current Issues in Tourism, 1-16.

Solarin, S. A. (2014). Tourist arrivals and macroeconomic determinants of $\mathrm{CO} 2$ emissions in Malaysia. Anatolia, 25(2), 228-241.

Tang, C. F., \& Abosedra, S. (2014). The impacts of tourism, energy consumption and political instability on economic growth in the MENA countries. Energy Policy, 68, 458-464.

Tang, C. F., \& Abosedra, S. (2016). Tourism and growth in Lebanon: new evidence from bootstrap simulation and rolling causality approaches. Empirical Economics, 50(2), 679-696.

Tang, C. F., \& Tan, E. C. (2015). Does tourism effectively stimulate Malaysia's economic growth?. Tourism management, 46, 158-163.

Tang, C. F., Tiwari, A. K., \& Shahbaz, M. (2016). Dynamic inter-relationships among tourism, economic growth and energy consumption in India. Geosystem engineering, 19(4), 158-169.

Westerlund, J. (2008). Panel cointegration tests of the Fisher effect. Journal of Applied Econometrics, 23(2), 193-233.

World Travel and Tourism Council (WTTC) (2019). Travel \& Tourism Economic impact 2019. World travel and tourism council.

Wu, T. P., \& Wu, H. C. (2019). Tourism and economic growth in Asia: A bootstrap multivariate panel Granger causality. International Journal of Tourism Research, 21(1), 87-96.

Yorucu, V. (2016). Growth impact of CO2 emissions caused by tourist arrivals in Turkey. International Journal of Climate Change Strategies and Management , 8 (1), 19-37.

Zaman, K., Shahbaz, M., Loganathan, N., \& Raza, S. A. (2016). Tourism development, energy consumption and Environmental Kuznets Curve: Trivariate analysis in the panel of developed and developing countries. Tourism Management, 54, 275-283. 
Zhang, L., \& Gao, J. (2016). Exploring the effects of international tourism on China's economic growth, energy consumption and environmental pollution: Evidence from a regional panel analysis. Renewable and Sustainable Energy Reviews, 53, 225-234. 